\title{
Sfide per comprendere la qualità della vita correlata alla salute delle persone che vivono con l'HIV: una misura del $4^{\circ} 90$ in Italia Challenges in understanding the health related quality of life of people living with HIV: a $4^{\text {th }} 90$ measure in Italy
}

\author{
Simone Marcotullio, David Osorio, Mattia Martini, Filippo von Schlösser \\ Nadir Onlus, Rome, Italy
}

\section{Riassunto}

II programma delle Nazioni Unite sulla sfida globale dell'HIV/ AIDS richiede che sia diagnosticato il $90 \%$ delle persone che vivono con I'HIV ("primo 90"), che il $90 \%$ di queste inizi la terapia antiretrovirale ("secondo 90") e che il $90 \%$ di queste ultime raggiunga una carica virale non rilevabile ("terzo 90"). Recentemente, è stato proposto un ulteriore "quarto 90 " e, di conseguenza, una nuova sfida: assicurarsi che il $90 \%$ delle persone con HIV e viremia non rilevabile abbia una buona Qualità della Vita Correlata alla Salute (acronimo in inglese: HRQoL). I due domini proposti da prendersi in considerazione per la sua stima sono le comorbilità e la qualità di vita auto-percepita, ma nell'articolo rimane un punto interrogativo su quali metodi e strumenti dovrebbero essere usati per la loro misura e quindi valutazione. A venti anni dalla sua costituzione, Nadir, un'associazione no profit di pazienti italiana riconosciuta, in conformità con i suoi obiettivi statutari, ha scelto un approccio pragmatico per la stima della HRQoL. In accordo con i suggerimenti dell'articolo e con l'obiettivo di valutare il divario nel raggiungimento del "quarto 90" in Italia, 407 persone con HIV e viremia non rilevabile hanno compilato un questionario ad hoc a risposta multipla, tra la fine del 2017 e l'inizio del 2018. Il campione comprendeva vari gruppi che riportavano le loro esperienze, dalla scoperta del loro status di HIV-positività all' inizio della terapia antiretrovirale. Nadir stima che in Italia la sfida del "quarto 90" sia stata raggiunta per il 60\%. I principali fattori negativi responsabili del non raggiungimento sono la scarsa salute sessuale e mentale, il rischio di isolamento e l'assenza di serenità, lo scarso interesse per il benessere a lungo termine e la stanchezza cronica.

\section{Abstract}

United Nations Programme on HIV/AIDS global challenge demands that $90 \%$ of people living with HIV are diagnosed ("first 90"), that 90\% of these are put in therapy ("second 90 ") and that $90 \%$ of the latter have an undetectable viral load ("third 90"). Recently, an additional "fourth 90" and consequently a new challenge have been proposed: to make sure that $90 \%$ of undetectable people with HIV have a good Health Related Quality of Life (HRQoL). Comorbidities and self-perceived quality of life are proposed domains to be taken into consideration for estimating HRQoL, but in the paper a question mark is left, concerning which methods and tools should be used for their evaluation. Twenty years following its formation, Nadir, an Italian recognized patient association, chose a pragmatic approach to estimate $H R Q o L$, in accordance with its statutory objectives. In accordance with paper suggestions, with the aim to evaluate the gap in achieving the "fourth 90" targets in Italy, an ad hoc multiple response questionnaire was administered from the end of 2017 to the beginning of 2018 to 407 undetectable People Living with HIV (PLHIV). The sample included various groups reporting their experiences, since discovering their HIV status until the initiation of antiretroviral therapy. Nadir estimates that in Italy the "fourth 90" challenge is achieved for its $60 \%$. The main responsible negative factors for its non-achievement are poor sexual and mental health, the risk of seclusion and the absence of serenity, poor interest about long-term well-being and chronic fatigue.

\section{Introduction}

Defining and measuring the concepts of Quality of Life (QoL) and Health-Related Quality of Life (HRQoL) have evolved over time.

A compelling narrative review was performed in
2014 by Marcel W.M. Post (1), who traced back the roots of the term "quality of life" in health care to the definition of health, given by the World Health Organization in 1948. Precisely from this date, the 2017 edition of the Italian Guidelines
Corrisponding Author:

Simone Marcotullio Nadir Onlus Vice-President Via Panama 88, 00198 Rome (Italy)

simone.marcotullio@gmail.com

Keywords:

Health-Related Quality of Life (HRQoL); Fourth Ninety (4th 90); comorbidities; self-perceived quality of life (self-perceived QoL); survey (questionnaire).

\section{Potenzial conflict}

of interest: see the end of the article

JHA 2018; 3(3): 57-61

DOI: 10.19198/JHA31453 
on the use of Antiretroviral Therapy and the diagnostic-clinical management of people with HIV-1 infection (2) addresses the topic, stating that $\mathrm{HRQOL}$ is a multidimensional measure that refers to the subjective perception that an individual has of his/her point of view in relation to all aspects of physical health, psychological state, social role, as well as his/her ability to fulfil the tasks of daily life in a satisfactory manner. This concept is based on the 1948 definition of health of the World Health Organization, according to which health is the state of complete physical, psychological and social well-being and not merely the absence of disease. In his review, Marcel W.M. Post emphasized that the use of the word "well-being" in this definition is probably the main factor in the continuing confusion about the concept of QoL (1).

A recent paper by Jeffrey $V$. Lazarus (3) linked HRQoL to United Nations Programme on HIV/ AIDS (UNAIDS) global challenge, claiming that it is necessary to put a Fourth Ninety (" 4 th $90^{\text {") }}$ challenge in place. The UNAIDS global "original" challenge demands that $90 \%$ of People Living with HIV (PLWH) are diagnosed ("first 90"), that 90\% of these are put in therapy ("second 90"), that $90 \%$ of the latter have undetectable viral load ("third 90 "), the paper claims that an additional target be put in place. This is that $90 \%$ of the undetectable population with HIV should have a good HRQoL. $\mathrm{HRQoL}$ is closely linked to the evaluation of two domains, comorbidities and self-perceived quality of life. However, a huge question remains, what the most appropriate methods and tools are to be used for evaluating HRQoL.

\section{How do PLWH really live? Measuring innovation today}

It is well recognized that measuring $\mathrm{HRQOL}$ regularly and using reproducible methods could provide a better understanding of the effects of HIV and HIV-medication on the lives of PLWH. It can also favour and encourage a holistic and social approach to this disease universally labeled as chronic. Going Beyond viro-immunological parameters is essentially the mantra of this philosophy and, by consequence, a good HRQoL should be the crucial target for the care-giving system.

Meaghan Kall and colleagues understood this target and 5 years ago initiated a study called Positive Voices (4), carried out by Public Health England (PHE), University College London and Imperial College London, financed by PHE and the pharmaceutical Gilead Sciences Inc. It began as a pilot randomized-controlled study designed to develop and evaluate the best method to deliver a cross-sectional, representative survey of PLWH. The study would need to be feasible and be implemented in clinical centers with the purpose of guaranteeing high response rates whilst requiring minimal resources to run. Recently, she presented in Edinburgh thought-provoking data at the joint British HIV Association (BHIVA) and British Association for Sexual Health and HIV (BASHH) conference, concerning loneliness and isolation of English PLWH (5), data confirmed by Meredith Greene (6) in San Francisco (USA).

Introducing measuring instruments that adequately consider the reality of PLWH today should be the priority. This is true not only because robust data to identify their met and unmet needs should be 'The Standard' for health policy makers to plan high quality and useful HIV services, but also because we need to understand the 'return of health' generated by innovation.

\section{Challenges for HRQoL to be an accountable indicator}

As explained, following Lazarus' ideas (3), the evaluation of good HRQoL and the challenge of measuring the $4^{\text {th }} 90$ are linked to the evaluation of two domains: comorbidities and self-perceived quality of life.

Here are some intrinsic and extrinsic criticalities:

- Both domains are closely tied to the environment, especially the management of comorbidities and the self-perceived quality of life. They are both country or even region specific.

- Considering that these two domains are not independent from one another, it means the variation of one implies the variation of the other.

- There are no universally recognized measures of these two variables and/or any particular aspects of them. In practice, it is hard to decide what can objectively be used in the creation of any sort of score/index. 
- These two variables (and/or their associated functions) must in some unknown way be related and suitably weighted for estimating HRQoL.

Moreover, as the Italian Guidelines stated (2), validated tools of QoL measures are often outdated and not suitable for capturing today's needs of PLWH (7-9). Furthermore, understanding the differentiation between clinical trials by assessing Patient Reported Outcomes can have an important role concerning some aspects of QoL (10) - and in relation to the real world setting, it is crucial for truly grasping the needs of PLWH.

\section{Nadir and HRQoL: material and methods}

For all the above said, twenty years after its formation, Nadir - an Italian recognized association for PLWH- in accordance with its statutory objectives (11), felt more than entitled to choose a pragmatic approach to measure/ estimate HRQoL. The aim was to evaluate the gap in achieving the $4^{\text {th }} 90$ target in Italy, which followed Lazarus' suggestions (3).

The specific questions (items) on certain aspects of life for undetectable PLWH were chosen following a focus group among Nadir members. It was decided that a linear, discrete and ascending score be used for every identified item (namely: very unsatisfactory, poor, normal, rather good, very good) and to assign "Good" (referring to good HRQoL) in case of 'rather good' and 'very good' choice. Percentages referring to $100 \%$ of the sample were generated. To be consistent with the $4^{\text {th }} 90$ target definition, that is achieving the status of ' $90 \%$ of undetectable PLWH having good HRQoL', percentages were transposed to $90 \%$ of the sample. Finally, these percentages (corresponding at most of the items) were renamed as indicators of' Health Condition ( $n=4)$, Social Well-Being ( $n=$ $5)$ and Disease/Disease Management $(n=4)$. The indicators were then graphed and compared to the ideal percentages corresponding to the $4^{\text {th }} 90$ target attainment level. The difference between them (i.e.: real versus ideal), in any kind of chosen representation, demonstrates how far off we are from achieving the target.

The items were selected in relation to two domains: comorbidities and self-perceived quality of life. Regarding comorbidities, Nadir explored the topic in several projects/surveys with the goal of evaluating HRQoL: it was decided to investigate aspects of everyday life, attempting to grasp the day to day challenges for a person with HIV dealing with comorbidities in the Italian healthcare system. On the other hand, regarding the self-perceived quality of life, to assess today's perception, Nadir decided to rely directly on the experiences of PLWH to point out the items. One disadvantage is the inability to make a comparison of QoL of a person living with HIV to that of the general population, but actually the real utility of this comparison remains unknown (12). As already noted, a further potential criticality is the intrinsic relationship that exists between the two domains,

Table 1. Topics, themes of the 38 multiple response questions (items) and indicators.

\begin{tabular}{|c|c|c|}
\hline TOPICS & ITEMS & INDICATORS \\
\hline $\begin{array}{l}\text { Life context and } \\
\text { social inclusion. }\end{array}$ & $\begin{array}{l}\text { Gender, age, education, } \\
\text { age of diagnosis, way } \\
\text { of HIV acquisition, rela- } \\
\text { tionship and professional } \\
\text { status, place of life. }\end{array}$ & \multirow{2}{*}{$\begin{array}{l}\text { Health conditions: } \\
\text { - Over all } \\
\text { - Physical } \\
\text { - Mental } \\
\text { - Sexual } \\
\text { Social Well-Being: } \\
\text { - Serenity } \\
\text { - Outing } \\
\text { - Planning the Future } \\
\text { (Future) } \\
\text { - Absence of Prejudice } \\
\text { (A-Prejudice) } \\
\text { - Absence of Seclusion/ } \\
\text { Loneliness (A-Seclusion) }\end{array}$} \\
\hline $\begin{array}{l}\text { Health conditions, } \\
\text { comorbidities and } \\
\text { HIV impact in life. }\end{array}$ & $\begin{array}{l}\text { Physical, mental, sexual, } \\
\text { overall health status, } \\
\text { experienced comorbidi- } \\
\text { ties, concern about futu- } \\
\text { re comorbidities, burden } \\
\text { of the disease, outing } \\
\text { with close persons, limi- } \\
\text { tations in planning the } \\
\text { future, HIV stigma and } \\
\text { discrimination, seeking } \\
\text { for social support. }\end{array}$ & \\
\hline $\begin{array}{l}\text { Relationship with } \\
\text { healthcare provi- } \\
\text { ders. }\end{array}$ & $\begin{array}{l}\text { Burden of dealing with } \\
\text { healthcare facilities/ } \\
\text { personnel and interfe- } \\
\text { rence with daily life, } \\
\text { quality and quantity of } \\
\text { time spent in dealing } \\
\text { with health facilities, } \\
\text { parcelling of facilities } \\
\text { and professionals. }\end{array}$ & \multirow{2}{*}{$\begin{array}{l}\text { Disease-Management/Dise- } \\
\text { ase Indicators } \\
\text { - Absence of Burden/inter- } \\
\text { ference with Everyday Life } \\
\text { (A-Burden) } \\
\text { - Potentially Good Adhe- } \\
\text { rence (Adherence) } \\
\text { - Interest about Long-Term } \\
\text { Well-Being (Long-Term) } \\
\text { - Absence of Fatigue } \\
\text { (A-Fatigue) }\end{array}$} \\
\hline $\begin{array}{l}\text { Adherence and } \\
\text { drugs availability, } \\
\text { long-term health } \\
\text { and HIV awareness. }\end{array}$ & $\begin{array}{l}\text { All therapies' schedules, } \\
\text { refill, availability, intake. } \\
\text { Proactivity in changing } \\
\text { therapies, optimization. } \\
\text { Symptomatology. Topics } \\
\text { of conversation with } \\
\text { the doctor. Trust in the } \\
\text { physician. }\end{array}$ & \\
\hline
\end{tabular}


Table 2. Positive Percentage Indicators.

\begin{tabular}{l|c}
\hline \multicolumn{1}{|c|}{ INDICATORS } & $\begin{array}{c}\text { PERCENTAGES (\%) } \\
\text { (Already transposed to } \\
90 \% \text { of the sample) }\end{array}$ \\
\hline $\begin{array}{l}\text { Health conditions: } \\
\text { 1. Over all }\end{array}$ & 57 \\
\hline 2. Physical & 63 \\
\hline 3. Mental & 54 \\
\hline 4. Sexual & 45 \\
\hline Social Well-Being: & \\
1. Serenity & 42 \\
\hline 2. Outing & 59 \\
\hline 3. Future planning (Future) & 57 \\
\hline 4. Absence of Prejudice (A-Prejudice) & 57 \\
\hline 5. Absence of Seclusion/Loneliness (A-Seclusion) & 43 \\
\hline Disease-Management/Disease: & \\
1. Absence of Burden/interference with Everyday & 62 \\
\hline Life (A-Burden) & 78 \\
\hline 2. Potential Good Adherence (Adherence) & 49 \\
\hline 3. Interest about Long-Term Well-Being (Long-Term) & 47 \\
\hline 4. Absence of Fatigue (A-Fatigue) & \\
\hline
\end{tabular}

especially when health conditions are proposed as indicators.

A questionnaire composed of 38 multiple response questions - with only one response option unless otherwise indicated - was posted for a period of 90 days (December 2017/February 2018) on Nadir website www.nadironlus.org, visited by approximately 20.000 people per month. In this period, three calls (December $17^{\text {th }}$, January $15^{\text {th }}$, February $15^{\text {th }}$ ) through Nadir mailing lists were sent to Nadir's networking system. Other patients' organizations and communities as well as clinicians helped Nadir in promoting the initiative. A flyer was also provided.

Topics explored were: 1. Life context and social inclusion (8 items); 2. Health conditions, comorbidities and HIV impact in life (11 items); 3. Relationship with healthcare providers ( 9 items); 4. Adherence and drug availability, long-term health and HIV awareness (10 items). Almost all items (listed in Table 1) contributed to form 13 indicators (also listed in Table 1). Data was analysed using descriptive statistics.

\section{Results}

407 PLWH completed the questionnaire: 327 were Males (80\%), 78 Females, 2 Transgender. The mean age was 46.4 years, the geographical distribution was balanced: North of Italy 58\%, Centre 29\%, South and Islands 13\%. Forty-two percent of compilers attended university and $44 \%$ high school, typical web surveys' figures. $31 \%$ were diagnosed with HIV before 2000, $26.5 \%$ from 2001-2010, 29\% from 2011-2015, $13 \%$ after $2015 ; 61 \%$ declared to have acquired HIV through sexual relations with people of the same sex. Forty-five percent were single, $50 \%$ in a relationship, 59\% with a stable work. Sixty-three percent described their overall health status "good" and 45\% declared to be satisfied with their lives. Comorbidities were faced by $86 \%$ of the sample. Among symptoms, fatigue seemed the most reported, to such an extent that we decided to include it within the cohort of good overall health status as a symptom characteristic of the disease.

To estimate HRQoL, 13 'Positive Percentage Indicators' were acquired from the items, analysed and scored. One such example is 'absence of Seclusion/Loneliness' as opposed to 'Seclusion/Loneliness' (Table 2).

Achieving the $4^{\text {th }} 90$ goal (i.e.: $100 \%$ of the target) would mean that $90 \%$ of Italian undetectable PLWH have a good HRQoL. According to the sample of this survey and with all the described limits of the methodology proposed here, not one of the goal indicators' measures were achieved. In particular, Italy stands at $60 \%$ of the target (please see Figure 1). The main negative factors for its non-achievement this consists of are: 1. Sexual and Mental Health; 2. The risk of Seclusion and the absence of Serenity; 3. Poor interest about Long-Term Well-Being and Chronic Fatigue.

\section{Conclusions}

Nothing about us, without us. Nothing is truer when we talk about HRQoL. In this area of research, patients' associations and/or HIVaffected communities must have a central role, being by definition an established observatory and recognized source of information. The limitations are very well known: this observatory most likely captured some fragile or specific populations. 
Therefore, we believe that our work must be considered as a pilot, and as a starting point, to be deepened and integrated together with other professional skills, to create a model structurally like that of PHE. However, institutional health sites used to collect data can result in generating strong biases in respondents' answers; furthermore, web surveys self-select the responding population: both these limitations must be overcome.

Achieving the $4^{\text {th }} 90$ target, measured with concrete indicators, seems to be a "theoretical target" to aspire to. In an overall evaluation, with all the limits reported, HRQoL of undetectable PLWH in Italy is not bad. Nadir wonders how we can at the very least preserve this level considering the growing demand for attention to clinical aspects, derived from aging and from the long-term effects of inflammatory pathology. Taking this into account, will HRQoL actually start gradually diminishing?

\section{Acknowledgments}

PLWH who completed the survey; Patient associations, the affected communities and HIV physicians, which promoted the survey.

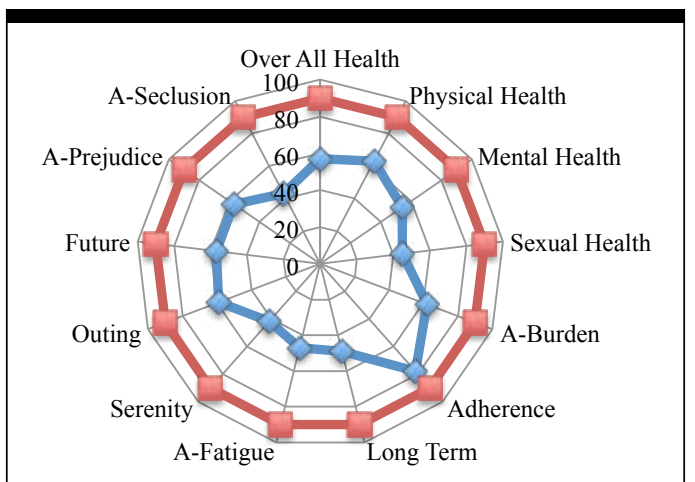

Figure 1. Indicators: survey values \% versus the ideal ones. (target to be achieved).

\section{Potential declaration of interests}

We declare that the carrying out of some activities related to this project were possible thanks to the support of Gilead Sciences and ViiV Healthcare.

\section{Note}

A preliminary analysis was presented at the tenth Italian Conference on AIDS and Antiviral Research (ICAR), Rome, May 2018, abstract OC 31.

\section{REFERENCES}

1. Post MWM. Definitions of Quality of Life: What Has Happened and How to Move On. Top Spinal Cord Inj Rehabil 2014; $20: 167-80$.

2. Italian Guidelines on the use of Antiretroviral Therapy and the diagnostic-clinical management of people with HIV-1 infection. 2017 Edition. http: //www.salute.gov.it/imgs/C_17_pubblicazioni_2696_allegato.pdf.

3. Lazarus JV, Safreed-Harmon K, Barton SE, et al. Beyond viral suppression of HIV - the new quality of life frontier. BMC Medicine $2016 ; 14$ : 94.

4. Kall M, Nardone A, Delpech, Gilson R, Shahmanesh M. 'Positive Voices' a survey of the behaviour, experiences, and healthcare needs of people living with HIV: A pilot study methods and respondent characteristics. HIV Medicine 2015; 16: 55-55.

5. Kall M, Kelly C, Auzenbergs M, Delpech V. Met and unmet health, welfare and social needs of people living with HIV. Fourth Joint Conference of the British HIV Association (BHIVA) with the British Association for Sexual Health and HIV (BASHH), Edinburgh, April 2018, abstract O23.

6. Greene M, Hessol NA, Perissinotto C, et al. Loneliness in Older Adults Living with HIV. AIDS and Behavior (2018) 22: 1475-84.

7. Cooper V, Clatworthy J, Harding R, Whetham J. Measuring quality of life among people living with HIV: a systematic review of reviews. Health Qual Life Outcomes 2017; 15: 220.

8. Pereira M, Martins A, Alves S, Canavarro MC. Assessing quality of life in middle-aged and older adults with HIV: psychometric testing of the WHOQoL-HIV-Bref. Qual Life Res. 2014; 23: 2473-9.

9. Wu AW, Hanson KA, Harding G. Responsiveness of the MOS-HIV and EQ-5D in HIV-infected adults receiving antiretroviral therapies. Health Qual Life Outcomes 2013; 11: 42.

10. Engler K, Lessard D, Lebouchè B. A Review of HIV-Specific Patient-Reported Outcome Measures. The Patient-Centered Outcomes Research 2017; 10: 187-202

11. Nadir Statute. https: //www.nadironlus.org/download/statutonadironlus2009.pdf.

12. Kelly C, Kall M, Auzenbergs M, Delpech V. Health-related quality of life of adults living with HIV in England and Wales: a utility analysis of EQ5D-5L compared to the general population. Fourth Joint Conference of the British HIV Association (BHIVA) with the British Association for Sexual Health and HIV (BASHH), Edinburgh, April 2018, abstract P284. 